\title{
Land use and occupation in the Fundaça Stream subbasin, Espírito Santo, Brazil
}

Caio Henrique Ungarato Fiorese ${ }^{1}$

\section{Abstract}

The objective of the research was to evaluate land use and occupation in the Fundaça Stream subbasin, state of Espírito Santo, Brazil, aiming at subsidizing improvements in environmental conservation and territorial planning. The procedures were performed in the ArcGIS ${ }^{\circledR}$ computer program. First, the study defined the limits of the subbasin, and then obtained the features of land use and occupation for the state of Espírito Santo from two mappings, from 2007 to 2008, and from 2012 to 2015 . These features were edited, defining the classes of use and occupation only for the subbasin. They were identified, quantified, and mapped. There is a predominance of pasture, with percentages above $50 \%$, although this occupation decreased by $1.94 \%$ between the periods studied. Coffee growing, the third predominant class, also decreased, which can be attributed to the preference for other activities, such as eucalyptus forestry. This showed strong growth, although with even lower percentages. Mishandling of those areas can cause environmental and economic damage. However, the areas of native vegetation represented a minimal rate, even with an increase, due to the decrease of vegetation in the early stage of regeneration. Macega (wild vegetation) coverage, besides being close to the native vegetation and which was predominantly fragmented, indicates problems with the use and occupation planning. The action of the local riverbasin committee and public managers, besides environmental education, and correct management of rural activities, are necessary actions.

Keywords: Geographical space. Geoprocessing. Environmental impacts. Mitigation. Territorial planning.

\section{Introduction}

As the population grows, there is more demand for new areas to meet the need for housing or developing activities such as livestock, forestry, and agriculture. However, in many situations, this causes the disorderly occupation of areas and the uncontrolled use of natural resources (NASCIMENTO; FERNANDES, 2017). The accelerated process of development of society has left strong marks on the Earth's surface, thus requiring - and with the same speed at which those transformations are processed - the systematic elucidation of possible changes in anthropic interference on the environment (LEITE; ROSA, 2012).

A watershed is a systemic unit in which there is a balance between rainfall entrance and water outflow, allowing for the delineation of basins and subbasins, interconnected through water flows. Human activities are developed in this territory, covering all urban, industrial, agricultural, or preservation areas. What happens there is a consequence, for example, of the forms of land occupation (PORTO; PORTO, 2008). Different environmental analyses can be carried out in the watersheds, to

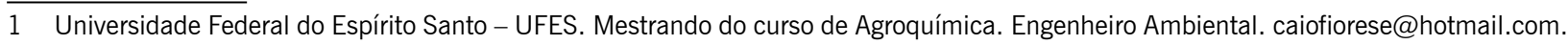


obtain information on the current local situation, providing adequate management to make perennial the existing natural resources, essential to human well-being (MOREIRA; FERNANDES; NERY, 2014).

Given the relevance of the watersheds, watershed committees (comitês de bacias hidrográficas- $\mathrm{CBH}$ ) were created, which are the public agencies responsible for discussing and deliberating on issues of common interest to different water users in a water basin. One of CBH's primary management resources is the Watershed Plan. Those committees are vital for the integrated management of water resources. For example, those groups propose public policies and decentralize and materialize the management, playing a strategic role in the National Water Resources Policy (TRINDADE; SCHEIBE, 2019).

Mapping land use and occupation is now an important tool that enables information that fosters the construction of environmental scenarios and indicators, such as subsidies for assessing environmental support capacity (MOREIRA; FERNANDES; NERY, 2014). Land use and occupation encompass information about the degree of preservation, conservation, or artificialisation of a particular place worldwide. The importance of their analysis in studies of environmental distinction is justified especially by the need to identify sources or potential sources of environmental changes. Thus, knowledge of the sources allows a decisive assessment on which actions must be taken into account to eliminate or reduce the changing factor (ALVES; CONCEIÇÃO, 2015). In the case of the Fundaça Stream watershed, studies focused on land use and occupation are especially important, as the region has been little researched. Another point is the severe problems that improper planning of land use may cause, such as soil erosion and agricultural productivity damage.

Lack of knowledge of land use aptitude and adequate land use planning has been a frequent negative factor impacting the environment (PEDRON et al., 2006). For example, land use and occupation significantly influence surface runoff and sediment intake in the waterbed and may modify the quality and availability of water resources (VANZELA; HERNANDEZ; FRANCO, 2010).

Land use and occupation mapping are based mainly on Geographic Information Systems (GIS) tools. Its use enables detailed environmental analyses. The use of GIS merges interdisciplinary bits of knowledge, aiming to achieve spatial information of all kinds. Thus, a geographical database is obtained, enabling several studies on the dynamics of the Earth's surface and, in turn, providing various cartographic products (BEZERRA JUNIOR; GUEDES, 2016). The treatment and generation of information about space through remote sensing techniques are essential for optimizing time and reducing costs in the field (FAUSTINO; RAMOS; SILVA, 2014).

Thus, the research objective was to analyze the land use and occupation in the subbasin of the Fundaça Stream, state of Espírito Santo, Brazil, to support improvements for soil and environmental conservation of this basin, combined with territorial planning.

\section{Materials and methods}

The study comprehended the Fundaça Stream Watershed (Bacia Hidrográfica do Córrego Fundaça - BHCF), which is in the rural area of the municipalities of Muqui and Mimoso do Sul, in the southern mesoregion of the state of Espírito Santo. It is a relevant basin for the supply of the district of Santo Antônio de Muqui, which has a population of 1,400 inhabitants. This region produces coffee, being agriculture, and cattle raising critical activities (PORTAL MIMOSO, 2020). According to editing data in a Geographic Information System, this subbasin has an area of $53.73 \mathrm{~km}^{2}$ and has its mouth in the Muqui do Sul River. Figure 1 shows the map of the area at stake, plotted through geographic 
data from municipalities in the state of Espírito Santo, obtained from the Jones dos Santos Neves Institute electronic portal (IJSN, 2020).

Figure 1 - Location of the Fundaça Stream watershed, Espírito Santo, 2020.

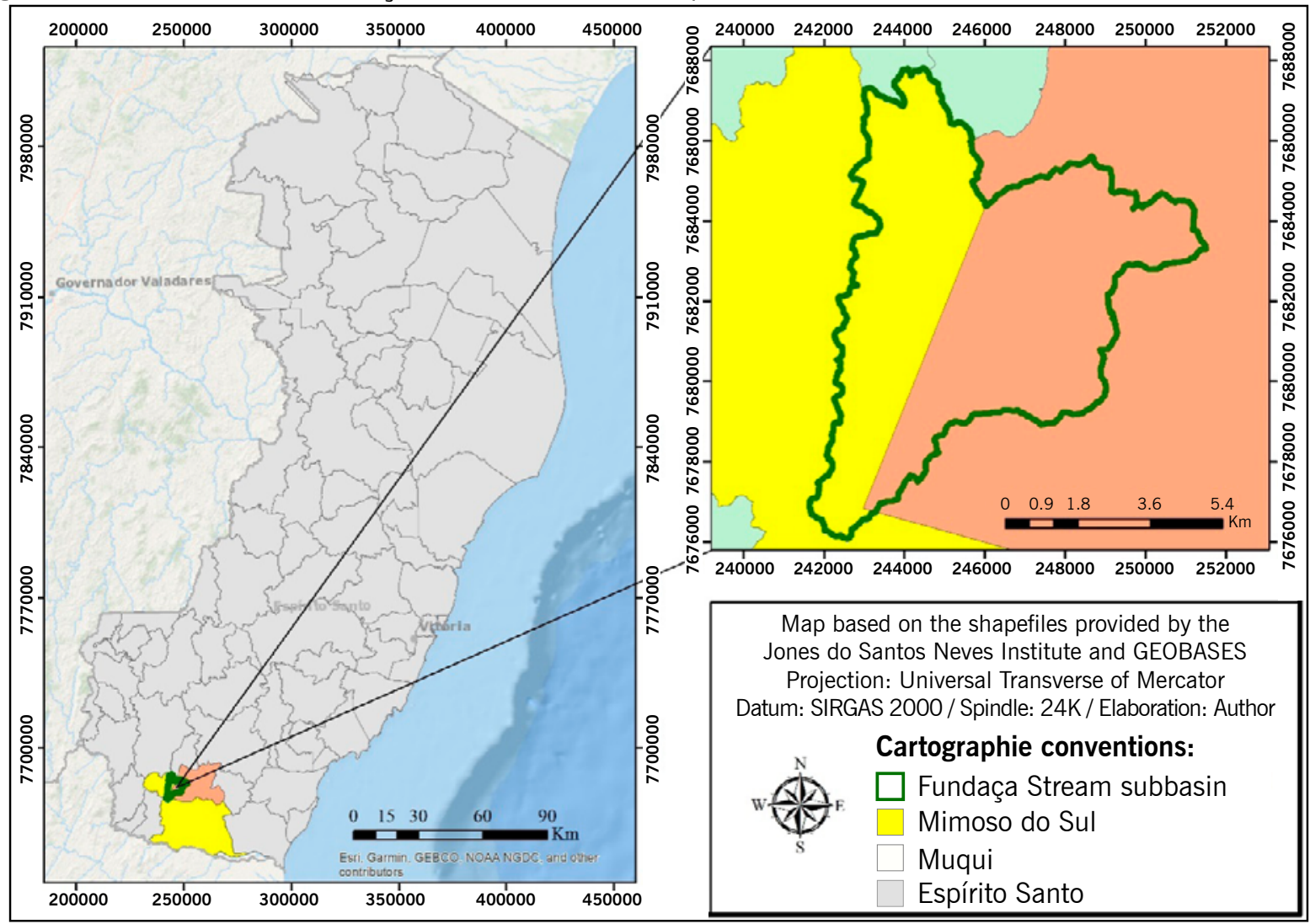

Source: Prepared by the author (2020), based on data from the Jones dos Santos Neves Institute (IJSN, 2020).

The procedures were subsidized by the geoprocessing technique, running them in the ArcGis $^{\circledR}$ computer program (ARCGIS, 2020). The geographic databases considered were the websites of the Integrated System of Geospatial Bases of the State of Espírito Santo (GEOBASES, 2020), the National Water Agency (ANA, 2020), and the Jones dos Santos Neves Institute (IJSN). Initially, the subbasin of interest was delimited, from the procedures mentioned by Santos, Louzada, and Eugenio (2010): acquisition of area-level curve features; generation of the Digital Elevation Model (MDE) and its subsequent correction; delimitation of the direction and accumulation of local drainage; extraction of the hydrographic mesh; identification of the main watercourse (in this case, the Fundaça Stream) from features of watercourses obtained on the National Water Agency (ANA) website, and demarcation of the BHCF outflow.

Subsequently, through GEOBASES, we obtained land use and occupation features for the state of Espírito Santo, referring to two mappings carried out: the first, from 2007 to 2008, and the second, from 2012 to 2015 . Both were on a scale equal to or better than 1:25000, according to GEOBASES. We produced the mappings on the orthophoto mosaics made available by GEOBASES, considering the photointerpretation procedures and manual vectorization of limits between the classes of land use and occupation identified. 
The mappings were represented by adjacent polygons submitted to topological validation to obtain the correct closure of these polygons and mitigate the overlap and appearance of voids between them. The minimum area of the polygons mapped was 0.50 ha, and the minimum accuracy index of the mapping was $90 \%$. We carried out field activities to solve all doubts in the identification of mapping classes. At this stage, we made registers of photographs and coordinates of the areas investigated (ESPÍRITO SANTO, 2020).

Features have been added to the program layout. With the aid of editing resources, land use and occupation classes were determined and delimited only for the BHCF. Through the table of attributes of the new use and occupation files generated, the classes were identified and quantified. Quantification in percentage occurred from the export of data, initially in square meters $\left(\mathrm{m}^{2}\right)$, to Microsoft Excel ${ }^{\circledR}$ spreadsheet. The mapping was carried out from the plotting of two thematic maps. Thus, quantitative information and maps allowed the execution of further studies based on the literature considered.

\section{Results and discussion}

The most comprehensive classes in the BHCF were agriculture and cattle raising (presence of pasture and coffee crops), native vegetation, native vegetation in the early stage of regeneration and macega. Table 1 shows the description of the classes identified and their respective percentages.

Table 1 - BHCF land use and occupation classes and respective percentages, Espírito Santo, 2020.

\begin{tabular}{lcc}
\hline \multicolumn{1}{c}{ Classes } & Years 2007-2008 & Years 2012-2015 \\
\hline Rocky Outcrop & $0.36 \%$ & $0.43 \%$ \\
Constructed Area & $0.03 \%$ & $0.04 \%$ \\
Bog & $0.64 \%$ & $0.44 \%$ \\
Agriculture - Banana & $0.00 \%$ & $0.15 \%$ \\
Agriculture - Coffee & $17.28 \%$ & $15.88 \%$ \\
Agriculture - Other Permanent Crops & $0.05 \%$ & $0.37 \%$ \\
Agriculture - Other Temporary Crops & $0.91 \%$ & $0.60 \%$ \\
Macega area & $6.30 \%$ & $6.56 \%$ \\
Water Body & $0.04 \%$ & $0.04 \%$ \\
Native Vegetation & $10.81 \%$ & $13.16 \%$ \\
Native Forest in Early-Stage Regeneration & $7.21 \%$ & $5.83 \%$ \\
Others & $1.53 \%$ & $2.48 \%$ \\
Pasture & $54.12 \%$ & $52.18 \%$ \\
Reforestation - Eucalyptus & $0.26 \%$ & $1.32 \%$ \\
Reforestation - Rubber tree & $0.23 \%$ & $0.26 \%$ \\
Soil exposed & $0.22 \%$ & $0.26 \%$ \\
\hline Source: Edited from $\%$ &
\end{tabular}

Source: Edited from GEOBASES (2020). 
The class that had the most significant increase was eucalyptus forestry, although it presented percentages below $2 \%$.

The highest percentage found was for "pasture," which occupies most of the BHCF, although it decreased by $1.94 \%$ in the period analyzed. The high predominance of pasture can be justified by the historical livestock relevance context. This activity has been essential in the Brazilian economy. It began to be developed in the sixteenth century, in the third decade after the beginning of the colonization process. It exerted a strong influence on economic expansion, highlighting the export agenda, and significant importance in the domestic market supply. Livestock continues to be practiced, in large part, in the traditional system of breeding, that is, cattle are raised loosely in natural pastures or planted in the extensive system (TEIXEIRA; HESPANHOL, 2014).

When mishandled, pasture becomes an environmental problem of significant magnitude, especially when it comes to traditional management techniques, such as the extensive system. Some of these negative environmental impacts are the destruction of the ecosystems, soil degradation through compaction and erosion, water resources pollution, and greenhouse gas emissions (DE ZEN et al., 2008).

Given this situation, actions taken to improve animal yield should lower the consumption of natural resources and increase animal digestive system efficiency (DE ZEN et al., 2008). An important measure to reduce overgrazing is the creation of silvopastoral systems, which improve the management of grazing systems such as crop-livestock integration. The environmental benefits of this technique are the conservation and renewal of natural resources by keeping trees in the grazing environment, since the large plants employed, such as timber, fruit, or forage, serve as food for animals (WÜST; TAGLIANI; CONCATO, 2015). Another important technique is the formation of pickets, as they allow better use of pasture areas associated with soil conservation, besides safeguarding more areas for forest preservation in rural properties (FIORESE; LEITE, 2018). These actions are fundamental to minimize the effects of the predominance of pasture in the BHCF, especially when there are soil mismanagement measures in the region.

In the water supply of the district of Santo Antônio de Muqui, the measures mentioned for pasture are extremely relevant and necessary, as they would contribute to more significant water infiltration into the soil and minimize the problematic effects of surface runoff and erosion in the region. Considering the predominance of rudimentary management techniques in livestock, as is the case with extensive livestock, such techniques could improve soil productivity and the quality of water resources used for water supply, and the economy.

Coffee growing was the third most comprehensive class seen. However, as well as pasture, it showed a decrease (equivalent to $1.40 \%$ ) in the period considered, revealing a decrease in agricultural activity in BHCF. The region's historical context also justifies the expressive occupation of local coffee culture and pasture. Coffee was brought to the state of Espírito Santo in the early nineteenth century, due to the expansion of cultivation areas of the Paraíba Valley. By the end of that century, coffee monoculture was already the predominant agricultural activity in the state (FERRÃO et al., 2007).

However, given the expressiveness of coffee culture, when mismanaged, soil degradation of those crops reduces water infiltration and increases runoff, causing groundwater lowering, erosion, flooding, and silting of rivers and reservoirs (SAMBUICHI et al., 2012). Although coffee crops have not caused negative effects on the native vegetation in BHCF when using traditional management 
techniques, they can cause adverse environmental impacts of great magnitude, and economic and quality damage to the local growers.

Simple practices indicated to prevent soil degradation, such as no-tillage in straw, planting in level curves, and crop rotation, are still little used by Brazilian farmers (SAMBUICHI et al., 2012). Other measures would also be of great relevance to stimulate the economic and more sustainable production of coffee in BHCF, such as the development of research, actions and participatory studies guided by the principles of agroecology, application of appropriate technologies for irrigation management, wastewater, and methods of natural control of pests and diseases, and expansion of financing and resources of rural credit specific to initiatives aimed at the transition from the traditional to the natural system (FERRÃO et al., 2007). Such measures are very relevant to the detriment of traditional soil management techniques in coffee crops, predominantly in the BHCF region.

Native vegetation showed much lower percentages in both mappings than other subbasins of similar studies, such as the Santo Amaro stream subbasin, 20.84 \% in the 2007-2008 mapping, and $20.21 \%$ in the 2012-2015 one (FIORESE; NASCIMENTO, 2019). However, it grew by $2.35 \%$, which can be credited to the reduction of other classes, especially the evolution of the class "native forest in early-stage regeneration," which, in turn, decreased by $1.38 \%$.

Native vegetation contributes to the maintenance of biodiversity and can also assist in water and edaphic resources (FRANCO et al., 2007). For the infiltration process, vegetation plays a determining role to the extent that it reduces the velocity of surface runoff, providing infiltration, which will supply groundwater and watercourses (FAUSTINO; RAMOS; SILVA, 2014). Therefore, the maintenance of the remnants and the expansion of native vegetation cover would be essential in BHCF, or else its shortage can bring losses in terms of environmental quality and economic productivity.

The "macega" class presented significant percentages considered, with the occupation rate increased by $0.26 \%$. This class coverage percentages were higher than those of river basins of similar studies, such as the Estrela do Norte stream subbasin with $3.49 \%$ and $3.00 \%$ in $2007-2008$ and 2012-2015, respectively (FIORESE; LEITE, 2018). This indicates a problem regarding BHCF land occupation, as these areas could be occupied by other classes, which would bring environmental services and more significant economic gains. An example of use could be native vegetation (FIORESE; NASCIMENTO, 2019).

Another interesting form of occupation would be agroforestry systems, which would enable more significant ecological, environmental, and economic benefits. These systems represent an important resource in the fight against poverty in rural areas, food security, conservation of natural resources, and are increasingly included in development programs implemented by various entities (PALUDO; COSTABEBER, 2012). These suggestions would bring several benefits to BHCF and could be adapted according to the natural conditions of the region and the economic conditions of the rural producers.

Although at low rates, eucalyptus areas increased in subbasins of similar studies, such as the Santo Amaro stream subbasin, with a growth of $2.65 \%$, according to Fiorese and Nascimento (2019). Eucalyptus crops can be both beneficial and harmful, depending on the physical conditions of the past. In environmental terms, reforestation would be less impactful if it were carried out in areas without native vegetation, with some degree of environmental degradation. An example of these areas is pastures and crops or crops that have been abandoned due to low productivity over time (OLIVEIRA; MENEGASSE; DUARTE, 2002). 
However, Oliveira and Almeida (2018) reported that eucalyptus forestry in the form of monocultures causes various environmental effects in the state of Espírito Santo. According to the authors, most impacts hit the physical and biological environments with adverse environmental changes. Soil and water characteristics are significantly affected and endangered species of flora and fauna.

However, an interesting alternative would be the adaptation of eucalyptus monoculture in agroforestry systems. This form of cultivation has proven to be a viable and sustainable economic option for small and medium-sized properties (MOSCA, 2008). This option would bring greater benefits to the eucalyptus areas of the BHCF and farmers in the region, also associated with the correct management of those crops. This alternative becomes even more relevant, given the growing trend of eucalyptus cultivated areas in the region, even though this growth of use in the basin under study was not observed in the period evaluated.

Among the primary mitigation and attenuation measures of the classes arising from anthropic action discussed is environmental education. Environmental education should be the fundamental resource for the participation of various sectors of society in awareness and involvement, whether in the identification of environmental problems or in the development of strategies that mitigate or solve their impacts. As an example, we can cite the reduction of disorders caused by the intensive use of pesticides in agriculture, which causes harm to human health and damage soil fertility (SANTOS; SILVA, 2017).

Moreover, the practice of environmental education is also beneficial for protecting other areas important for biodiversity and which have not been discussed previously, as is the case with the bogs and water resources of BHCF. Environmental education, for BHCF, would be fundamental for better planning of land use and occupation combined with the correct land occupation, in line with the environmental quality of this area. The other classes, due to their low percentages or because they did not undergo drastic increase or reduction, were not discussed much in this work.

Figures 2 and 3 present land use and occupation maps for 2007 to 2008 and 2012 to 2015, respectively. 
Figure 2 - Map of land use and occupation during 2007-2008, Fundaça stream watershed, 2020.

Classes
Rocky Outcrop
Bog
Agriculture - Coffee
Agriculture - Other Permanent Crops
Agriculture - Other Temporary Crops
Macega Area
Water Body
Native Vegetation
Native Forest in Early-Stage Regenerations
Others
Pasture
Reforestation - Eucalyptus
Reforestation - Rubber Tree
Soil Exposed
Constructed Area

Source: Prepared by the author (2020).

Figure 3 - Map of land use and occupation during 2012-2015, Fundaça stream watershed, 2020.

\begin{tabular}{|l} 
Classes \\
Rocky Outcrop \\
Bog \\
Agriculture - Banana \\
Agriculture - Coffee \\
Agriculture - Other Permanent Crops \\
Agriculture - Other Temporary Crops \\
Macega Area \\
Water Body \\
Native Vegetation \\
Native Forest in Early-Stage Regenerations \\
Others \\
Pasture \\
Reforestation - Eucalyptus \\
Reforestation - Rubber Tree \\
Soil Exposed \\
Constructed Area
\end{tabular}

Source: Prepared by the author (2020). 
Figure 4 shows the changes in land use and occupation from 2012 to 2015 for the classes: pasture, eucalyptus, rubber tree, exposed soil, and unidentified classes (other classes).

Figure 4 - Map of land use and occupation class changes from 2007-2008 to 2012-2015, Fundaça stream subbasin, 2020.

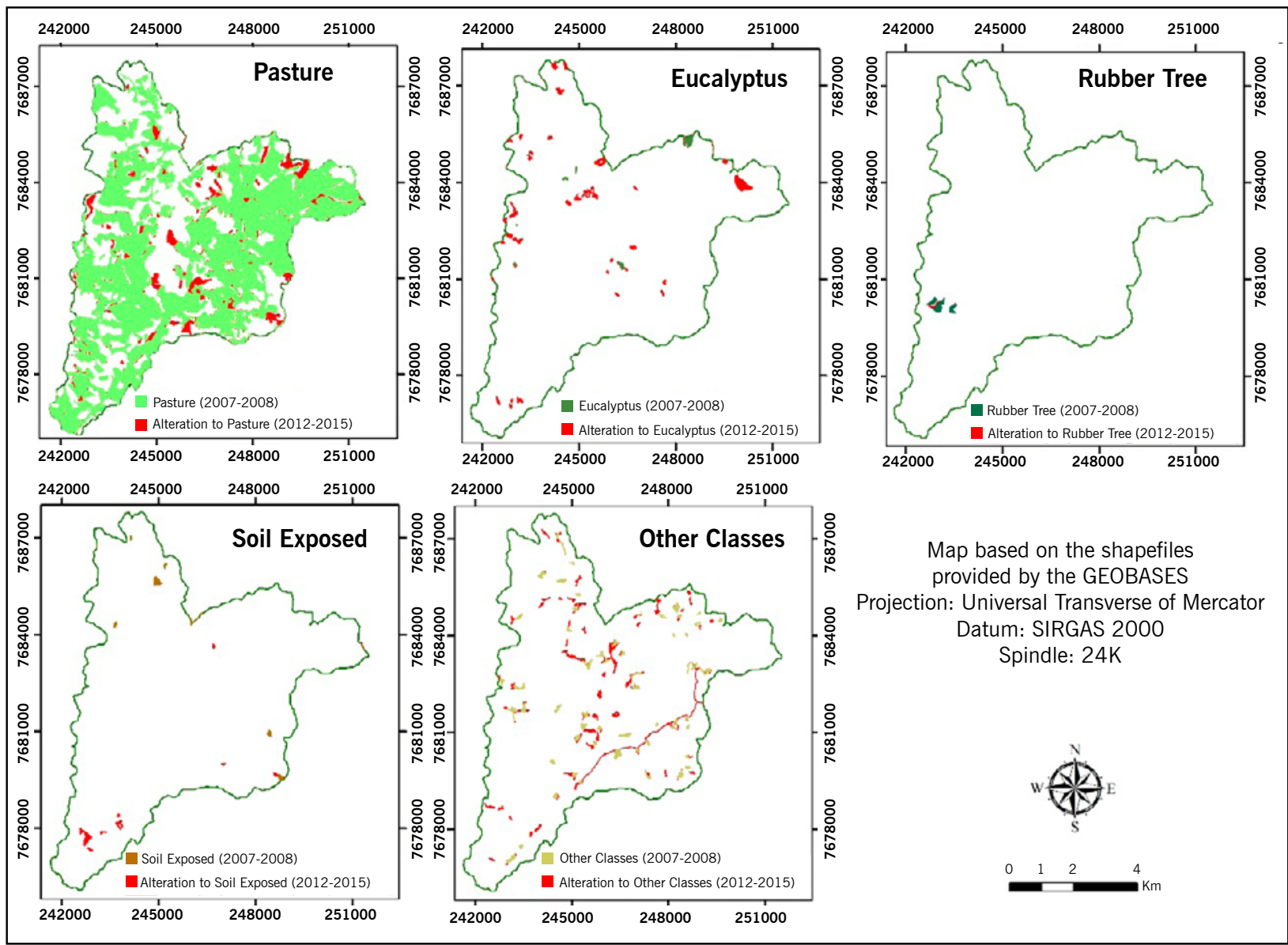

Source: Prepared by the author (2020).

Figure 5 shows the changes in land use and occupation from 2012 to 2015 for the classes: rocky outcrop, bog, coffee, other permanent crops, other temporary crops, macega, native forest, and native forest in early-stage regeneration. 
Figure 5 - Map of land use and occupation class changes from 2007-2008 to 2012-2015, Fundaça stream subbasin, 2020.

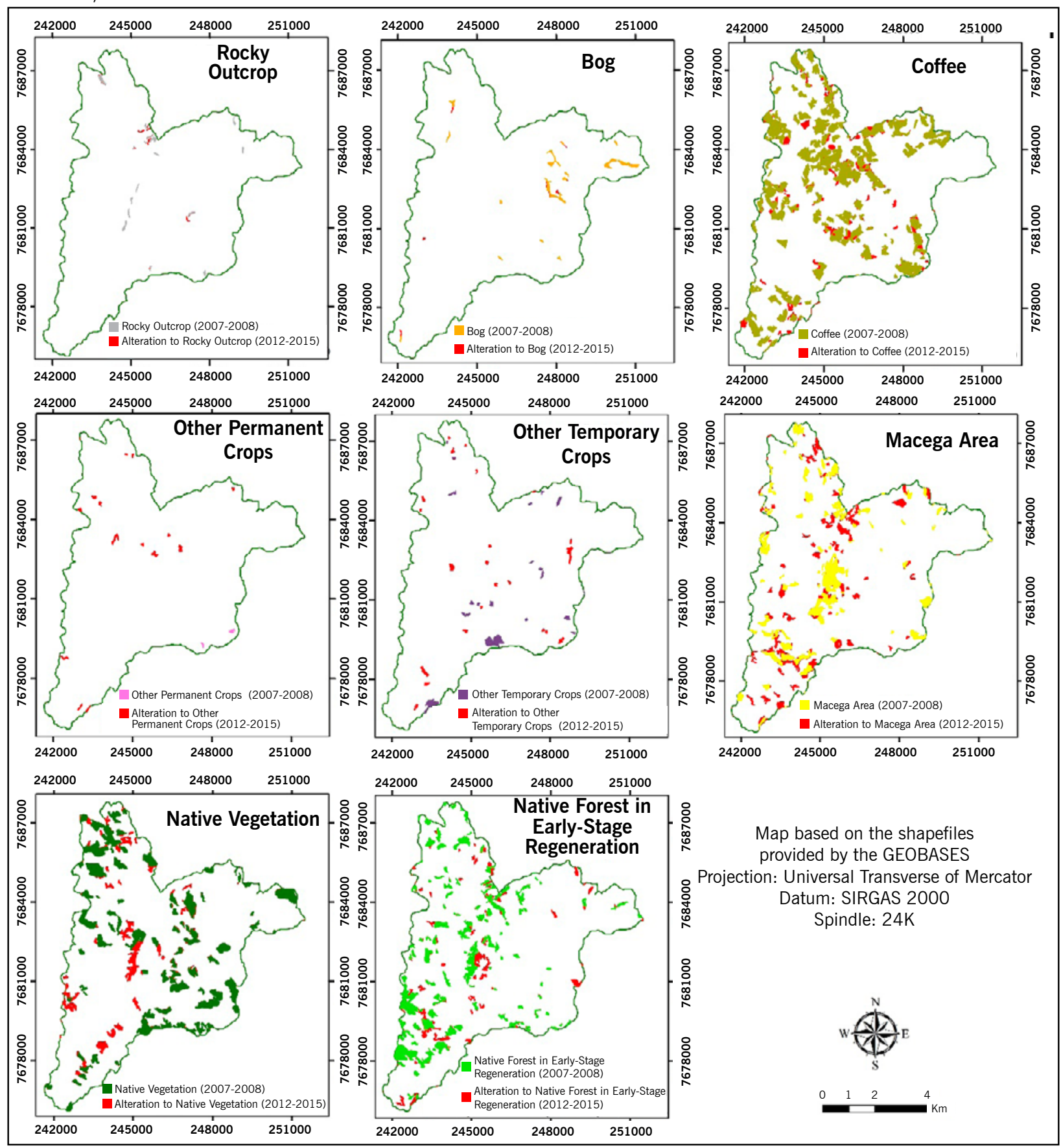

Source: Prepared by the author (2020).

The classes "Agriculture - Banana" and "Constructed Area" were not represented in the maps of changes of each class, because there was a minimal increase (by $0.01 \%$ ) of built area, which to the naked eye is very difficult to perceive. Bananiculture, on the other hand, because it was represented only in the 2012-2015 mapping, was geospatialised in the map of land use and occupation of the 2012-2015 mapping (FIGURE 3). 
We can observe that the predominance of pasture occurs all over the subbasin. Eucalyptus areas practically increased at a specific point, which was formerly occupied by pasture. Thus, as reported in the discussion of the quantitative data of that class of use and occupation, the environmental benefits become greater, especially if that pasture area was degraded. However, this eucalyptus crop needs proper management; otherwise, it can become an environmental problem.

However, most of the BHCF shows the occupation of native vegetation in the form of forest fragments. This visualized fragmentation can be attributed to the misuse of natural resources and land occupation in a disorderly manner, which has suppressed several areas of relevant biological characters, such as primary forests and secondary vegetation (VERONESE, 2009).

The degradation of native forests results from the complex interaction between factors inherent to the fragmentation process, such as reduction of the area, greater exposure to the edge effect and isolation, and constant anthropic pressure. These factors manifest and combine in different ways, generating various forms of degradation. Consequently, a unique mosaic of units is created for each fragment (VIANA; PINHEIRO, 1998). Therefore, the forest fragmentation seen for the BHCF results from incorrect planning of use and occupation. In terms of environmental conservation, the connection of those fragments and the gradual recovery of degraded areas of the subbasin would be relevant.

In this sense, an interesting measure that could be adopted is the creation of ecological corridors. They constitute a strategy of adopting public policies and integrated management to ensure species' survival, the maintenance of evolutionary ecological processes, regional economic development, social inclusion, and the rational use of natural resources (ARANA; ALMIRANTE, 2007). This feature would bring a connection between nearby fragments and, in environmental terms, is an excellent suggestion for BHCF.

Another factor that evidences the incorrect planning of the forms of occupation is macega fragments near areas of native vegetation and, mainly, native vegetation in an early stage of regeneration. Through environmental reforestation programs, those areas could be better used to bring more ecosystem and economic benefits. Moreover, the use of those areas through agroforestry systems, as discussed by Paludo and Costabeber (2012), is an excellent suggestion for ecology, sustainability, and economy.

\section{Conclusion}

The subbasin studied has low quantities of native vegetation cover, which, in turn, is distributed in the form of fragments in a large part of the area.

The high expressiveness of macega, especially near areas of native vegetation, evidence problems regarding land use and occupation planning in BHCF.

The strong presence of agricultural activity requires proper management of local lands; otherwise, it can cause severe environmental and economic problems.

The importance of the action of the watersheds local committee and other public managers, the environmental education practice with the residents of the region, and the correct soil management to the detriment of traditional cultivation techniques are evidenced. 


\section{Uso e ocupação das terras na sub-bacia hidrográfica do Córrego Fundaça, Espírito Santo, Brasil}

\section{Resumo}

O objetivo da pesquisa foi avaliar o uso e a ocupação das terras na sub-bacia hidrográfica do Córrego Fundaça, no estado do Espírito Santo, com vistas a subsidiar melhorias em conservação ambiental e planejamento territorial. Os procedimentos foram realizados no programa computacional $\operatorname{ArcGIS}^{\circledR}$. Inicialmente foi delimitada a sub-bacia estudada para, em seguida, serem adquiridas feições de uso e ocupação das terras para o Estado do Espírito Santo referentes a dois mapeamentos: o primeiro, nos anos de 2007 a 2008; o segundo, de 2012 a 2015. Tais feições foram editadas delimitando as classes de uso e ocupação somente para a sub-bacia. As classes foram identificadas, quantificadas e mapeadas. Há predominância de pastagem, com percentuais acima de 50 \%, embora esta ocupação tenha decrescido em 1,94 \% entre os períodos estudados. A cafeicultura, terceira classe predominante, também decresceu entre os períodos analisados, o que pode ser atribuído à preferência por outras atividades, como a silvicultura do eucalipto. Esta apresentou um forte crescimento, embora com percentuais ainda baixos. Tais áreas, caso manejadas incorretamente, acarretam danos ambientais e econômicos. Todavia, as áreas de vegetação nativa representaram percentual muito pequeno, mesmo com aumento, devido ao decréscimo da vegetação em estágio inicial de regeneração. A abrangência da macega somada ao fato de que ela esteve próxima da vegetação nativa e predominantemente fragmentada indicam problemas de planejamento de uso e ocupação. A atuação do comitê local de bacias hidrográficas e gestores públicos, além da educação ambiental e do manejo correto das atividades rurais, são ações necessárias.

Palavras-chave: Espaço geográfico. Geoprocessamento. Impactos ambientais. Mitigação. Planejamento territorial.

\section{References}

AGÊNCIA NACIONAL DE ÁGUAS - ANA. Encontre mapas interativos, conjuntos de dados geográficos, imagens de satélite e outros serviços. Disponível em: https://metadados.ana.gov.br/geonetwork/srv/ pt/main.home. Acesso em: 10 mar. 2020.

ALVES, A. C.; CONCEIÇÃO, P. E. A. Levantamento do uso e ocupação do solo por meio de imagens TM-Landsat-5 e ADS-80 para o município de Manaus/AM. In: Simpósio Brasileiro de Sensoriamento Remoto. 2015, João Pessoa. Anais... João Pessoa: 17, 2015, p. 5881-5888.

ARANA, A. R. A.; ALMIRANTE, M. F. A importância do corredor ecológico: um estudo sobre o Parque Estadual "Morro do Diabo" em Teodoro Sampaio-SP. Geografia, Londrina, v. 16, n. 1, p. 143-168, jan./jun. 2007. Disponível em: http://www.uel.br/revistas/uel/index.php/geografia/article/view/6578. Acesso em: 24 abr. 2020. 
ARCGIS. ArcGIS: software. Disponível em http://www.esri.com/software/arcgis/index.html. Acesso em: 10 jan. 2020.

BEZERRA JUNIOR, A.; GUEDES, J. A. Caracterização e análise do uso e ocupação da terra no entorno do reservatório Santana, Rafael Fernandes/RN. Revista OKARA: Geografia em debate, João Pessoa, v. 10, n. 3, p. 517-530, 2016.

DE ZEN, S.; BARIONI, L. G.; BONATO, D. B. B.; ALMEIDA, M. H. S. P. de.; RITTL, T. F. Pecuária de corte brasileira: impactos ambientais e emissões de gases efeito estufa (GEE). Piracicaba: Centro de Estudos Avançados em Economia Aplicada, 2008.

ESPÍRITO SANTO. Instituto Estadual de Meio Ambiente e Recursos Hídricos. Referência técnica. Disponível em: https://geobases.static.es.gov.br/public/MAP_ES_2012_2015/MAP_ES_2012_2015_ REFEENCIA_TECNICA.pdf. Acesso em: 21 nov. 2020.

FAUSTINO, A. B.; RAMOS, F. F.; SILVA, S. M. P. da. Dinâmica temporal do uso e cobertura do solo na Bacia Hidrográfica do Rio Doce (RN) com base em Sensoriamento Remoto e SIG: uma contribuição aos estudos ambientais. Sociedade e Território, Natal, v. 26, n. 2, p. 18 - 30, jul./dez. 2014. Disponível em: https://periodicos.ufrn.br/sociedadeeterritorio/article/view/5305. Acesso em: 11 abr. 2020.

FERRÃO, R. G.; FONSECA, A. F. A. da.; BRAGANÇA, S. M.; FERRÃO, M. A. G.; DE MUNER, L. H. Café Conilon. Vitória: Instituto Capixaba de Pesquisa, Assistência Técnica e Extensão Rural, 2007. 702 p.

FIORESE, C. H. U.; LEITE, V. R. Dinâmica do uso e cobertura do solo na sub-bacia hidrográfica do Ribeirão Estrela do Norte no município de Castelo, Estado do Espírito Santo. Agrarian Academy, Goiânia, v. 5, n. 10, p. 52-65, 2018. Disponível em: http://www.conhecer.org.br/Agrarian\%20 Academy/2018B/dinamica.pdf. Acesso em: 22 abr. 2020.

FIORESE, C. H. U.; NASCIMENTO, W. A. R. do. Mapeamento do uso das terras na sub-bacia hidrográfica do Ribeirão Santo Amaro, no Sul do Estado do Espírito Santo. Enciclopédia Biosfera, Goiânia, v. 16, n. 29, p. 1554-1566, 2019. Disponível em: http://www.conhecer.org.br/enciclop/2019a/ agrar/mapeamento.pdf. Acesso em: 12 abr. 2020.

FRANCO, G. A. D. C.; SOUZA, F. M. de.; IVANAUSKAS, N. M.; MATTOS, I. F. A.; BAITELLO, J. B.; AGUIAR, O. T.; CATARUCCI, A. F. M.; POLISEL, R. T. Importância dos remanescentes florestais de Embu (SP, Brasil) para a conservação da flora regional. Biota Neotrópica, v. 7, n. 3, p. 145-161, 2007. Disponível em: https://www.scielo.br/scielo.php?pid=S1676-06032007000300017\&script=sci_ arttext. Acesso em: 24 abr. 2020.

GEOBASES. IEMA - mapeamento ES - 2012-2015. Disponível em: https://geobases.es.gov.br/linkspara-mapes1215. Acesso em: 10 mar. 2020.

INSTITUTO JONES DOS SANTOS NEVES - IJSN. Shapefiles. Disponível em: http://www.ijsn.es.gov. br/mapas/. Acesso em: 11 mar. 2020.

LEITE, E. F.; ROSA, R. Análise do uso, ocupação e cobertura da terra na bacia hidrográfica do Rio Formiga, Tocantins. OBSERVATORIUM: Revista Eletrônica de Geografia, v. 4, n. 12, p. 90-106, 
dez. 2012. Disponível em: http://www.observatorium.ig.ufu.br/pdfs/4edicao/n12/05.pdf. Acesso em: 10 abr. 2020.

MOREIRA, A. A.; FERNANDES, F. H. S.; NERY, C. V. M. Mapeamento e análise do uso e ocupação do solo na bacia do Rio Vieira no município de Montes Claros/MG. Revista Brasileira de Geomática, Pato Branco, v. 2, n. 2, p. 40-48, jul./dez. 2014. Disponível em: https://periodicos.utfpr.edu.br/ rbgeo/article/view/5448. Acesso em: 11 abr. 2020.

MOSCA, A. A. de O. Avaliação dos impactos ambientais de plantações de eucalipto no Cerrado com base na análise comparativa do ciclo hidrológico e da sustentabilidade da paisagem em duas bacias de segunda ordem. 2008. 256 p. Tese (Doutorado). Universidade de São Paulo, São Paulo.

NASCIMENTO, T. V. do.; FERNANDES, L. L. Mapeamento de uso e ocupação do solo em uma pequena bacia hidrográfica da Amazônia. Ciência e Natura, Santa Maria, v. 39, n. 1, p. 170-178, jan./abr. 2017. Disponível em: https://periodicos.ufsm.br/cienciaenatura/article/view/21737. Acesso em: 06 abr. 2020.

OLIVEIRA, J. de A.; ALMEIDA, F. S. Alterações ambientais provocadas pela silvicultura no Estado do Espírito Santo. In: SIMPÓSIO DE GESTÃO AMBIENTAL E BIODIVERSIDADE. 2018, Três Rios. Anais... Três Rios: 7, 2018, p. 256-259.

OLIVEIRA, F. R. de.; MENEGASSE, L. N.; DUARTE, U. Impacto ambiental do eucalipto na recarga de água subterrânea em área de cerrado, no médio vale do Jequitinhonha, Minas Gerais. Revista Águas subterrâneas, São Paulo, p. 1-10, 2002. Disponível em: https://aguassubterraneas.abas.org/ asubterraneas/article/view/22677. Acesso em: 27 abr. 2020.

PALUDO, R.; COSTABEBER, J. A. Sistemas agroflorestais como estratégia de desenvolvimento rural em diferentes biomas brasileiros. Revista Brasileira de Agroecologia, v. 7, n. 2, p. 63-76, 2012. Disponível em: https://orgprints.org/22937/1/Paludo_Sistemas\%20agroflorestais.pdf. Acesso em: 24 abr. 2020.

PEDRON, F. de A.; POELKING, E. L.; DALMOLIN, R. S. D.; AZEVEDO, A. C. de.; KLANT, E. A aptidão de uso da terra como base para o planejamento da utilização dos recursos naturais no município de São João do Polêsine - RS. Ciência Rural, Santa Maria, v. 36, n. 1, p. 105-112, jan./fev. 2006. Disponível em: https://www.scielo.br/pdf/cr/v36n1/a16v36n1.pdf. Acesso em: 05 abr. 2020.

PORTAL MIMOSO. Santo Antônio do Muqui. 2020. Disponível em: http://www.portalmimoso.com. br/distritos/santoantoniodomuqui/index.html. Acesso em: 10 mai. 2020.

PORTO, M. F. A.; PORTO, R. la L. Gestão de bacias hidrográficas. Estudos Avançados, São Paulo, v. 22, n. 63, p. 43-60, 2008. Disponível em: https://www.scielo.br/scielo.php?script=sci_arttext\&pid=s010340142008000200004\&l. Acesso em: 06 abr. 2020.

SAMBUICHI, R. H. R.; OLIVEIRA, M. A. C. de.; SILVA, A. P. M. da.; LUEDEMANN, G. A sustentabilidade ambiental da agropecuária brasileira: impactos, políticas públicas e desafios. Rio de Janeiro: Instituto de Pesquisa Econômica Aplicada, 2012. 52 p. 
SANTOS, A. R. dos.; LOUZADA, F. L. R. de O.; EUGENIO, F. C. ArcGIS 9.3 total: aplicações para dados espaciais. 2.ed. Alegre: CAUFES, 2010. 184 p.

SANTOS, F. R.; SILVA, A. M. A importância da educação ambiental para graduandos da Universidade Estadual de Goiás: Campus Morrinhos. Interações, Campo Grande, v. 18, n. 2, p. 71-85, abr./jun. 2017. Disponível em: https://www.scielo.br/pdf/inter/v18n2/1518-7012-inter-18-02-0071.pdf. Acesso em: 27 abr. 2020.

TEIXEIRA, J. C.; HESPANHOL, A. N. A trajetória da pecuária bovina brasileira. Caderno Prudentino de Geografia, Presidente Prudente, v. 1, n. 36, p.26-38, jan./jul. 2014. Disponível em: https:// revista.fct.unesp.br/index.php/cpg/article/view/2672. Acesso em: 23 abr. 2020.

TRINDADE, L. de L.; SCHEIBE, L. F. Gestão das águas: limitações e contribuições na atuação dos comitês de bacias hidrográficas brasileiros. Ambiente \& Sociedade, São Paulo, v. 22, p. 1-20, 2019. Disponível em: https://www.scielo.br/pdf/asoc/v22/1809-4422-asoc-22-e02672.pdf. Acesso em: 14 jan. 2020.

VANZELA, L. S.; HERNANDEZ, F. B. T.; FRANCO, R. A. M. Influência do uso e ocupação do solo nos recursos hídricos do Córrego Três Barras, Marinópolis. Revista Brasileira de Engenharia Agrícola e Ambiental, Campina Grande, v. 14, n. 1, p. 55-64, 2010. Disponível em: https://www.scielo.br/ scielo.php?script=sci_arttext\&pid=S1415-43662010000100008. Acesso em: 10 abr. 2020.

VERONESE, J. V. Análise de fragmentos florestais e proposição de corredores ecológicos com base no Código Florestal - Lei 4.771/65: aplicação na Serra do Brigadeiro - MG. 2009. 56 p. Trabalho de Conclusão de Curso (Especialização). Universidade Federal de Juiz de Fora, Juiz de Fora.

VIANA, V. M.; PINHEIRO, L. A. F. V. Conservação da biodiversidade em fragmentos florestais. Série Técnica IPEF, v. 12, n. 2, p. 25-42, dez. 1998. Disponível em: https://www.ipef.br/publicacoes/ stecnica/nr32/cap03.pdf. Acesso em: 25 abr. 2020.

WÜST, C.; TAGLIANI, N.; CONCATO, A. C. A pecuária e sua influência impactante ao meio ambiente. In: CONGRESSO BRASILEIRO DE GESTÃO AMBIENTAL. 2015, Porto Alegre. Anais... Porto Alegre: 6, 2015, p. 1-5.

Received: May 19, 2020

Accepted: November 26, 2020 